\title{
Impact of Interest Rate Differential and Exchange Rate Movement on the Dynamics of Nigeria's International Private Capital Flows
}

Tari M. Karimo ${ }^{1}$

The study examines the impact of interest rate differential and exchange rate movement on the dynamics of Nigeria's international private capital flows from 2010Q1 to 2019Q4. It uses the interest rate parity theory and the Markov Switching Time Varying Transition Probability Modelling approach. Findings show that interest rate differential does not explain the dynamics of aggregate capital and Foreign Direct Investment (FDI) flows, but significantly explains Foreign Portfolio Investment (FPI) flows. Also, Movement in real exchange rate is significant in explaining outflows and inflows in FPI, and inflows in FDI, but neutral to aggregate capital flows. The study concludes that deviations from interest rate parity provides opportunities for interest rate and currency arbitrage in Nigeria but using aggregate capital flows mask this evidence. The study therefore recommends that the CBN should focus on exchange rate stabilization policies, so as not only to discourage FPI reversal but to also enhance FDI inflow. This can be done by putting in place foreign reserve accretion measures to boost the ability of the CBN to defend the Naira. The new policy initiative on remittances is a right step in the right direction as it could boost external reserve.

Keywords: Arbitrage, capital flow, exchange rate, interest rate parity, time varying transition probability

JEL Classification: F31, F41

DOI: $10.33429 /$ Cjas. $11220.2 / 8$

\section{Introduction}

Economists have over the years sought to explain the determinants of capital flows among economies. Consequently, there are two main strands of thought providing explanations of the mechanism governing capital mobility across national boundaries. These are the Resource Gap Theory (RGT) and the Interest Rate Parity Theory (IRPT). The RGT argues that countries that are closed to international capital mobility would have their income equal to expenditure on consumption and investment. Countries that are integrated into the world financial market could finance the discrepancies between income and expenditure through

\footnotetext{
${ }^{1}$ Statistics Department, Central Bank of Nigeria.

The views/opinions expressed in this paper are those of the author and do not in any way represent the views of the Central Bank of Nigeria.
} 
international borrowing or lending (Chenery \& Stout, 1966; Thirlwall, 1976). The RGT has been supported by findings from Kim, Kim and Wang, (2007) for EU countries, Drakos, et al (2017) for Asian countries and Adegboye, et al. (2020) for sub-Saharan Africa countries. The IRPT describes the idea of parity between interest rate differentials and forward premium and provides reasons why the Interest Rate Parity (IRP) might not hold (Keynes, 1923). Further, the main reason for capital mobility is because parity does not always hold between interest rate differential and exchange rate movement. The theory has since developed into becoming an important theory in modern international finance (see Georgoutsos \& Kouretas 2016; Lothian, 2016; Ames, Bagnarosa, \& Peters, 2017; Park \& Park, 2017; Vasilyev, Busygin, \& Busygin, 2017; Ismailov, \& Rossi, 2018; Adewuyi \& Ogebe, 2019).

From Chenery and Stout, (1966) and Thirlwall, (1976) a large body of literature has emerged on the use of foreign capital to bridge foreign exchange gap with the benefits of technology spillover and transfer of managerial skills (see Caves 1974; Mansfield \& Romeo, 1980; Aitken \& Harrison, 1994; Blomström, Kokko \& Zejan, 1994; Barry \& Bradley, 1997; Bosworth, Collins \& Reinhart, 1999; Konings, 2001; Buckley, et al., 2002; Schoors \& Tol, 2002; Basu, Chakraborty \& Reagle, 2003; Kose, Prasad, \& Terrones, 2009; Caporale, Donadelli \& Varani, 2015; Djordjevic, Ivanovic \& Bogdan, 2015; Okereke \& Ebulison, 2016; Nwosa \& Adeleke, 2017; Enisan, 2017; Ning \& Zhang, 2018;Wang, Su, \& Tao, 2019).

The perceived benefits associated with capital importation presents opportunity for emerging market and developing economies to attract foreign capital but with weak governance structures, poor macroeconomic management, and underdeveloped financial systems, attracting investors could be a herculean task. Consequently, a study of the dynamics of international private capital flows is predicated on the suitability of domestic policy design and investment decisions. From a policy perspective, the determinants of international capital flows, particularly the interest rate parity must be properly understood and effectively managed to attract and keep foreign investors to avoid capital outflows and currency crisis. For economies heavily reliant on international capital, a sudden halt or huge reversals could impose difficulties on domestic macroeconomic stability. Such was the case of the East Asian emerging economies in 1997 when the collapse of the Thai baht triggered a sequence of unprecedented currency crises in East Asia. Earlier, these economies had enjoyed relatively high asset values/yield resulting in massive capital inflows to finance productive investments. The continuous capital 
inflows resulted in the appreciation of the domestic currencies with a simultaneous decline in asset yields. In Thailand, exchange rate pressures built up, forcing the government to abandon its currency peg in July 1997, leading to the eventual collapse of the Thai baht. Within a space of four months, the currency depreciated by about $60 \%$. Investors reassessed the strength of the currency peg and the financial system in the region, resulting in a wave of currency depreciations and declining assets in the stock market as investors withdrew their investments in favour of foreign markets with better yields. The impact was first felt across the entire South-East Asia due to the similarity of these markets (see Moreno, 1998; Yamazawa, 1998).

Various scholars have studied the determinants of international capital flows in different countries, including Nigeria (see Taylor \& Sarno, 1997; Çulha, 2006; Glauco \& Kyaw, 2008a; Glauco \& Kyaw, 2008b; Brana \& Lahet, 2010; Förster, Jorra, \& Tillmann, 2012; Byrne \& Fiess, 2015; Bogdan 2016; Grzegorz, Brzozowski \& Śliwiński, 2017; Maghori, 2014; Obida \& Abu, 2010; Ibrahim \& Omoniyi, 2011; Essien \& Onwioduokit, 1999; Okereke \& Ebulison, 2016; Nwosa \& Adeleke, 2017; Enisan, 2017; Nwokoye \& Oniore 2017; Leonard, 2018). However, the causes of capital reversals in emerging economies, especially the role of interest rate differentials and exchange rate movements, are hardly examined, making it difficult to distinguish between policy actions that reverse or perpetuate outflows and policy actions that sustain or perpetuate inflows. More so, except for Leonard (2018) previous studies either aggregate net capital flows without considerations for the components or focused on one component only, mostly FDI. Except for Enisan (2017), previous studies for Nigeria did not account for capital outflow. Studies in Nigeria including Enisan (2017) were also not carried out within the interest rate parity framework and so did not account for the influence of interest rate differential, and exchange rate movement simultaneously. There is, therefore, no empirical evidence that opportunity for arbitrage exists in the Nigerian economy.

There are two major types of international private capital flows - Foreign Direct Investment (FDI), and Foreign Portfolio Investment (FPI). A third which has become important in recent years is remittances (see World Bank, 2020, 2019a, b \& c, 2018a \& b, \& 2016). This study, however, focuses on FDI and FPI only, because these are the conventional types of foreign private capital flows. Also, the exclusion of remittances is due to its impact on exchange 
rate, which is well documented in the literature and could lead to problem of endogeneity in a study of the impact of exchange rate on capital flows (Adejumo \& Ikhide, 2019; Khurshid, et al., 2017; Lartey, 2017; Amuedo-Dorantes, 2014; Singer, 2010).

This study therefore examines the impact of interest rate differential and movements in real exchange rate on FDI, FPI and aggregate international capital inflows and outflows in an IRP framework. The study contributes to the body of literature by unveiling the relevance of interest rate differential and movements in exchange rates as determinants of the component of private capital inflows and outflows from 2010Q1 to 2019Q4. It thus highlights that when capital flows are aggregated, the impact of important determinants could be masked since the same factors could have differential impact on different types of capital flows, and the perpetuation of inflows and outflows, respectively.

The rest of the study is set out as follows: Section 2 is literature review; Section 3 is the data and methodology; Section 4 is the results and discussion; and Section 5 provides the conclusion and policy recommendation.

\section{Literature Review}

\subsection{Theoretical Literature}

There are two main strands of thought that provide explanations on the mechanism governing capital mobility across national boundaries. These are summed in the Resource Gap Theory (RGT) and the Interest Rate Parity Theory (IRPT). Whereas the RGT argued that it is the deficits in domestic resources in meeting investment and consumption needs that drive economies to seek capital elsewhere, the IRPT maintained that it is the difference between asset yields (interest differential) and exchange rate forward premium that determines the direction of international capital flow.

The RGT is attributed to Chenery and Stout (1966) and expanded by Thirlwall (1976). Chenery and Stout (1966) argued that domestic savings do not always equal investment. When savings fall short of investment, a savings-investment gap emerges. To bridge this gap, the government would either borrow from the home economy or from overseas thereby creating a foreign exchange gap. This is the amount by which the investment requirement falls short of the foreign exchange earnings. The difference between these two gaps determines the source of funding the deficit. The gap may be financed through domestic sources if the 
saving-investment gap is larger relative to the foreign exchange gap otherwise financing will be from international sources. A key assumption of the RGT is that, in a world where there are no barriers to capital mobility there would be zero correlation between changes in domestic investment and national savings (Feldstein \& Horioka, 1980; Feldstein, 1983; Obstfeld, 1981). The RGT is not explicit about the role of interest rate differential and exchange rate movement, which this study examines.

This study is anchored on the Interest Rate Parity Theory (IRPT). The IRPT was formalized and popularized by Keynes (1923). In his "A tract on monetary reform" Keynes (1923) described the idea of parity between interest rate differentials and forward premium and provides reasons why the IRP might not hold (see Georgoutsos \& Kouretas 2016; Lothian, 2016; Ames, Bagnarosa, \& Peters, 2017; Park \& Park, 2017; Vasilyev, Busygin, \& Busygin, 2017; Ismailov, \& Rossi, 2018; Adewuyi \& Ogebe, 2019).

The IRPT assumes identical yields on assets, for instance, treasury bills of different countries with similar quality (in terms of maturity, liquidity, and other macroeconomic conditions like capital control exposure and default risk) but differ only in the underlying currency. In its simplest form the IRPT holds when the interest rate differential between any two countries equals the difference between the exchange rate futures and spot rate. In which case there is no arbitrage for investors to take advantage of and the yield from investing in any of the country's assets is equal. Therefore, there is no economic incentive to seek investment outside one's domestic economy. Any deviation from parity creates arbitrage opportunities. To take advantage of the opportunity, international investors borrow from countries with lower interest rate and invest in countries with higher rates (Teall, 2018). The result is capital outflow for the lower interest rate economy and inflow for the higher interest rate economy. Thus, interest rate differentials and movements in exchange rates are thought of as the main drivers of international private capital flows (Keynes, 1923 and Levich, 2011).

\subsection{Empirical Literature}

The literature provides evidence on important global and country-specific factors determining capital flows in developing economies (see Taylor \& Sarno, 1997; Çulha, 2006; Glauco \& Kyaw, 2008a; Glauco \& Kyaw, 2008b; Brana \& Lahet, 2010; Förster et al., 2012; Byrne \& Fiess, 2015; Bogdan 2016; Grzegorz et al., 2017) including those relating to the interest rate parity theory (see Dooley, 1988; Wang \& He, 2007; Su \& Zhang, 2010; Fang, Pei, \& 
Zhang, 2012; Cheung, Sven, \& Frank, 2016; Ning \& Zhang, 2018). Also, there are studies for Nigeria in the literature suggesting different determinants of foreign capital flow (Essien \& Onwioduokit, 1999; Obida \& Abu, 2010; Ibrahim \& Omoniyi, 2011; Maghori, 2014; Okereke \& Ebulison, 2016; Nwokoye \& Oniore, 2017; Nwosa \& Adeleke, 2017; Enisan, 2017; Leonard, 2018).

Studies relating to developing economies abound in the literature. For instance, Taylor and Sarno (1997) investigated the determinants of portfolio flows from the United States to Latin American and Asian countries during 1988-1992 using cointegration and an error correction model. The study suggests that both domestic and global factors explain bond and equity flows to developing countries and are important long-run determinants of portfolio flows. This position is supported by Glauco and Kyaw (2008a), Glauco and Kyaw, (2008b) and Brana and Lahet (2010). Glauco and Kyaw, (2008a) in another study applied panel cointegration technique on data generated from a panel of thirty-two developing countries during 1990-2004 and provide evidence to show that domestic productivity growth and domestic money growth are key factors driving FDI and portfolio investment inflows to developing countries. In another study, Glauco and Kyaw (2008b) examined push and pull factors determining FDI and portfolio inflows to five developing countries by applying a structural VAR approach on quarterly data for the period 1976-2001 and showed that shocks to foreign output and domestic productivity are the key determinants of capital inflows to developing countries. Brana and Lahet (2010) studied the impact of external and domestic factors on capital inflows to four Asian countries within a panel framework during 1990-2007 and argued that both push and pull factors are important determinants of capital inflow to Asian countries. However, push factors such as carry trade strategies, global liquidity and contagion factors are key determinants. Förster, Jorra and Tillmann (2012) using a dynamic hierarchical factor modelling approach for a large set of industrial and emerging economies also provides evidence that country-specific factors explain the largest proportion of dynamics of capital inflows. Byrne and Fiess (2015) provided similar findings when they studied a sample of 78 countries within a macro panel framework for the period 1993Q1 to 2009Q1. The study also provides evidence that aggregated and disaggregated capital inflows responds differently to shocks. 
Bogdan (2016) using correlation analysis and ordinary least square regression technique studied the impact of push and pull factors in Ukraine for the period 2004:Q1-2014:Q4 and showed that foreign bond spread is mainly driven by push factors and increase in commodity prices, and that increase in commodity prices attracts capital to Ukraine. This supports the findings of Çulha (2006) who applied a Structural VAR approach within the Pull-Push factor framework to post-crisis Turkey during 1992:01 - 2015:12 and showed however, that the relative importance of some factors changed over time and that the determinants of capital flows in Turkey is dominated by pull factors.

Dooley (1988) using a pooled regression technique on annual data for six developing countries during 1976-1983 suggests that while yield differentials may not be an important driver of capital flight, differences in perceived risk of domestic and foreign investors in holding claims on residents of the domestic economy is a significant determinant. Dooley measures perceived risk (yield differential) as changes in the difference between domestic interbank rate and the US 91-day T-Bill rate.

Grzegorz, et al. (2017) applying a Bayesian model averaging (BMA) on thirty-three emerging and nineteen developed economies opined that equity investment is a more desirable form of foreign capital flow since debt inflows are more responsive to global factors and are therefore more volatile. Findings from Grzegorz et al. (2017) reveals that the influence of macroeconomic and portfolio related variables on capital flows depends on the type of capital inflow and the group of countries involved, which reinforces the results of Förster, et al. (2012) suggesting that global factors and country-specific factors are important for countries with more developed financial systems, and that a fixed exchange rate regime does not impede the dynamics of global capital flows.

While Su and Zhang (2010), Ning and Zhang (2018), Wang, Su, and Tao (2019) all showed evidence supporting the importance of interest rate on international capital flow, but Cheung, Sven and Frank, (2016) suggest otherwise. Specifically, Su and Zhang, (2010) using the quadruplex arbitrage model investigate the impact of interest and tax differences between China and America on China's short-term capital flow during 2002:01 - 2009:12. They report that interest rate arbitrage and tax accelerates short-term capital inflow. Ning and Zhang (2018) using the Markov switching time varying transition probability (MS-TVTP) model and data for the period 2000:M01-2015:M10 studied the dynamics of China's short-term 
international capital flow and argues that exchange rate and interest rate arbitrages are important factors determining capital inflows or outflows. Wang, Su, and Tao (2019) examined the causal link of short-term capital flow and interest rate differential using bootstrap Granger full-sample causality and sub-sample rolling-window methods. The study which covered the period 2009:M01-2018:12 suggests a unidirectional causality from interest rate differential to short-term capital flow to China. Cheung et al. (2016) studied China's capital flow and suggest that capital flight, measured by trade mis-invoicing fails to respond to disparities in interest rate parity in the post-2007 period but significantly to quantitative easing, exchange rate variability, capital control and trade frictions.

Studies on Nigeria mostly used the cointegration and error correction modelling approach and reported contrasting results. These studies include Maghori (2014) for the periods 19702010, who suggests that the major determinant of FDI inflows into Nigeria is external debt. Obida and Abu (2010) shows that foreign direct investment in Nigeria is determined by the host country's market size, deregulation, political instability, and exchange rate appreciation. Leonard (2018) who disaggregated foreign investment into FDI and FPI during the period 2007 - 2017 also suggests that exchange rate appreciation impacts negatively on foreign direct investment and foreign portfolio investment in Nigeria. This result is supported by Ibrahim and Omoniyi (2011) who studied the determinants of Foreign Direct Investment (FDI) in Nigeria during 1970 - 2006. In addition to corroborating findings from Obida and Abu (2010), a study by Essien and Onwioduokit (1999) for the period 1970-1997, suggests that the rate of returns on asset are critical to FDI inflows. Okereke and Ebulison (2016) study during the period 1970-2011 was in tandem with Obida and Abu (2010) but suggests in addition that, interest rate is not an important factor determining FDI inflows to Nigeria. Nwokoye and Oniore (2017) study for the period 1994-2015 used autoregressive distributed lag technique and shows that broad money supply, nominal exchange rate, inflation rate and interest rates spread are the major determinants foreign capital flows to Nigeria. Nwosa and Adeleke (2017) focused on volatility in FDI and FPI in Nigeria over the period 19862016 and show that trade openness and world GDP are key determinants of volatility of FDI flows to Nigeria, and that the domestic interest rate and stock market capitalization are relevant for FPI volatility. Enisan (2017) used the Markov-regime switching model (MSMs) for the period 1970-2012 and suggests that exchange rate, inflation, and discount rate are the important variables determining FDI flows. 
The literature reviewed suggest a variety of methods used in the study of international capital flows. Taylor and Sarno (1997) used cointegration and seemingly unrelated error correction model approach. While Dooley (1988) used a pooled regression technique, Glauco and Kyaw, (2008a), Brana and Lahet (2010), applied panel cointegration technique, Byrne and Fiess (2015) used a macro panel data approach and Glauco and Kyaw, (2008b) and Çulha (2006) used a structural VAR approach. Förster et al. (2012) and Bogdan (2016) used dynamic hierarchical factor modelling approach, and correlation analysis and ordinary least square regression technique, respectively. Whereas Grzegorz, et al. (2017) applied a Bayesian model averaging (BMA), Su and Zhang, (2010) used the quadruplex arbitrage model, and Wang et al. (2019) used bootstrap Granger full-sample causality and sub-sample rolling-window methods.

From the foregoing a key gap observed in the literature is a dearth of studies on the sensitivity of factors to the state of capital flows (inflow and outflow regimes), making it difficult to distinguish between policy actions that reverse or perpetuate outflows and policy actions that sustain or perpetuate inflows. More so, most empirical studies on the determinants of capital flows adopt net capital flows as the measure of capital flows. This aggregation could mask relevant information on determinants of specific types of capital flows as Grzegorz et al. (2017) and Förster, et al. (2012) reports. This difference could serve as an important guide to investors in maximizing the profitability of their portfolios.

Furthermore, except for Nwosa and Adeleke (2017), Leonard (2018) and Enisan (2017) who used EGARCH, VAR and Markov-regime switching models, respectively, other studies for Nigeria all used cointegration and error correction models and did not account for capital outflows. Also, none of the studies was carried out within the interest rate parity framework, including Enisan (2017) who used the Markov-regime switching model and so did not account for the influence of interest rate differential, and exchange rate movement simultaneously. In addition, they mostly focused on FDI flows without recourse FPI flows, an important source of international capital. Leonard (2018) who disaggregated capital flows and Nwokoye and Oniore (2017) who studied exchange rate and interest rate differential simultaneously did not account for capital outflows. 


\subsection{Stylized Facts}

One important measure of the role of international private capital flows mostly used in literature is the ratio of investment flow to GDP (see Feldstein \& Horika, 1980; Feldstein, 1983; Calvo et al., 1993; Förster et al., 2012; Enisan, 2017). It shows the share of the investment (or investment component) in the economy. This study computes this measure and estimates the mean value for the full sample 2010Q1 to 2019Q4, and subsamples 2010Q1 to 2014Q4 and 2015Q1 to 2019Q4 to reveal the importance or otherwise of foreign investment flow to Nigeria. The period from 2010Q1 to 2014Q4 is important in analyzing recent macroeconomic fundamentals in Nigeria for some reasons. During this period, the economy was relatively stable with a calmer foreign exchange market as the real effective exchange rate declines from N95.17 in 2010Q1 to N68.54 in 2014Q4 (CBN, 2020) showing that the naira is relatively stronger. The period starting from 2015Q1 to 2019Q4 is relatively more volatile. The 2015 elections (elections in Nigeria are marked with violence), the issue of increased insecurity arising from farmers herders crisis and banditry, the negative news that took over the information space (news like "Nigerians are fantastically corrupt") and the economic recession which occurred in 2016Q2 all happened within this period, making it significant in the economic history of Nigeria. The foreign exchange market during this period was more volatile with attendant depreciation in the value of the naira. The real effective exchange rate rises from N73.37 in 2015Q1 to N101.76 in 2017Q2. The domestic currency however appreciates in 2019Q4 as indicated by the decline in the real effective exchange rate to N78.92 in 2019Q4 (CBN, 2020). Table 1 reports the mean values of foreign capital-GDP ratio for the full and subsamples.

Table 1: Foreign Private Investment share of GDP in Nigeria, 2010Q1 to 2019Q4

\begin{tabular}{llll}
\hline Sample & FDI & FPI & TFPI \\
\hline 2010Q1 - 2014Q4 & 0.90 & 1.18 & 2.08 \\
2015Q1 - 2019Q4 & 0.41 & 0.57 & 0.98 \\
Full Sample & 0.65 & 0.88 & 1.53 \\
\hline
\end{tabular}

Notes: (i) FDI is Foreign Direct Investment (ii) FPI is Foreign Portfolio Investment (iii) TFPI is total Foreign Private Investment. (iv) all variables have been divided by real Gross Domestic Product.

Source: Author's Computation. 


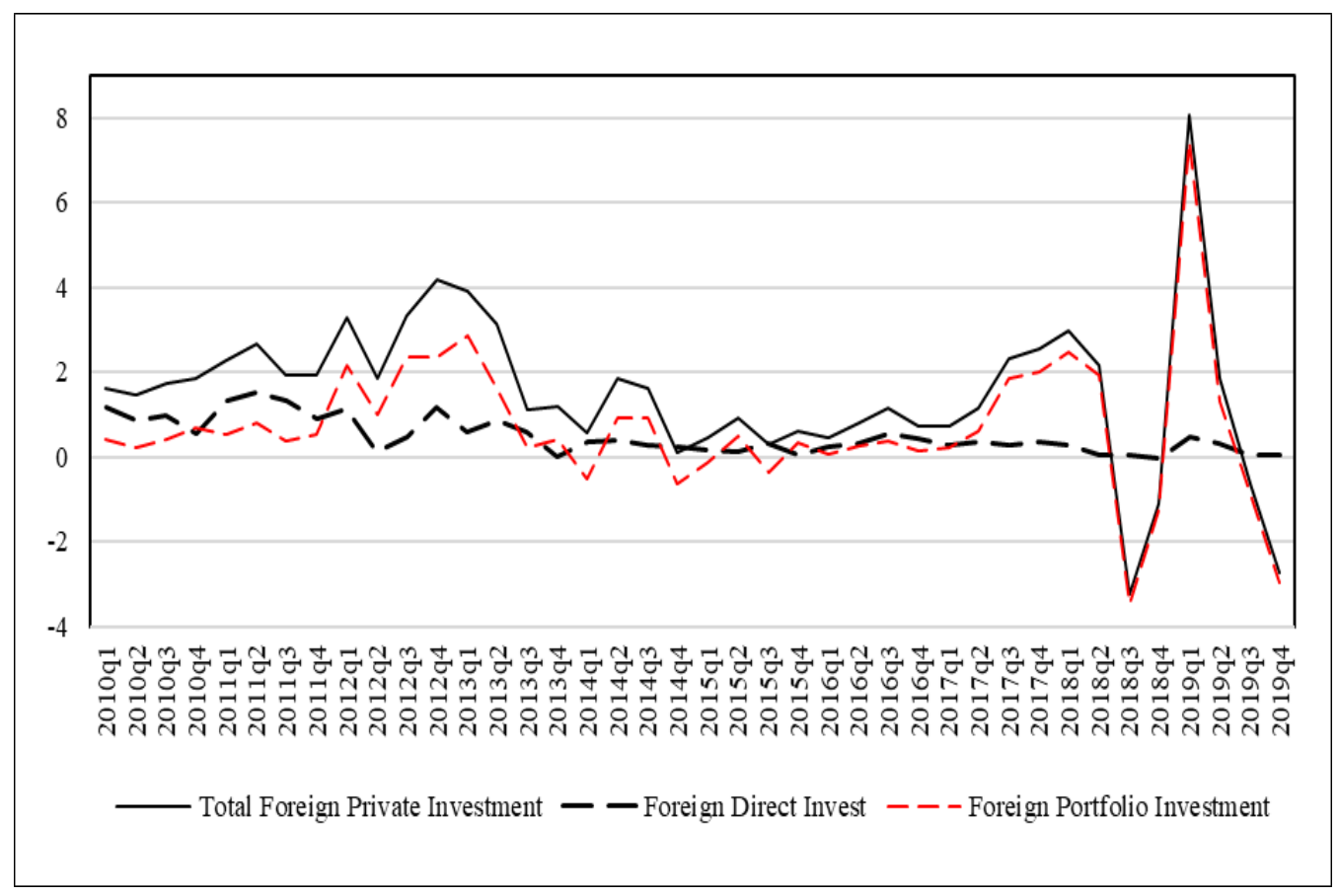

Figure 1: Foreign Private Capital Flow in Nigeria as percentage of GDP.

The importance of foreign investment in Nigeria has declined over the years within the sample period from 2.08\% of GDP between 2010Q1 and 2014Q4 to $0.98 \%$ between 2015Q1 and 2019Q4. This pattern is also observed in each of FDI and FPI. This is not surprising since the economic recession, which started in 2016Q2 falls within the period. This could have dampened investors' confidence since investors are interested in returns on investment. However, this does not preclude the fact that capital reversals could be partly responsible for the recession since negative news dominated the country's information space during the period and Nigeria experienced a decline in capital flow, and in some instances capital reversal (see Figure 1). To show a more lucid picture of capital movement, especially the relative importance of the components, Figure 1 is relevant.

FDI which was more important from 2010Q1 to 2011Q4 diminished both in relative and absolute terms, and almost disappeared from the 'radar'. Foreign portfolio investment is the more important component of foreign private investment in Nigeria starting from 2012Q1. This could pose some challenges for macroeconomic management since FPI, a short-term capital flow is speculative and volatile. Any dip in FPI reflects a major outflow of investment. 
This is evident in Figure 1 where in 2018Q3, 2019Q1, Q3 and Q4 negative FPI flows result in negative values of total foreign investment flows representing capital reversal. For 2014Q1, Q4 and 2015Q3 when FDI is the major driver, negative values of FPI did not matter much.

The notion that FPI is relatively more volatile is widely accepted in literature. Figure 1 only shows the relative importance of each component but not the drivers. Understanding the macroeconomic fundamentals that drive the dynamics of capital flow, including its components is important for short term policy analysis. The Hodrick-Prescott filter with a smoothing parameter of 1600 is used to decompose the variables into their cyclical components. The variables include Foreign Private Capital flow and its components, FDI and FPI, real effective exchange rate, Nigeria and US 91-day treasury bill rates (proxies for domestic and foreign interest rates, respectively) and their difference (proxy for interest rate differential), and push factors of crude oil price and relative real GDP. To explore the drivers of the dynamics of capital flow and macroeconomic fluctuations Table 2 reports the standard deviation of the cyclical components of these variables for the full sample, 2010Q1 to 2019Q4 and the subsamples, 2010Q1 to 2014Q4 and 2015Q1 to 2019Q4. Using the cyclical components allow for a measure of volatility in relation to the business cycle.

Table 2: Volatility of Foreign Private Capital Flows

\begin{tabular}{llll}
\hline Variable & Full Sample & $\begin{array}{l}\text { Subsamples } \\
2010 \mathrm{Q} 1-\end{array}$ & \\
& $2010 \mathrm{Q} 1-2019 \mathrm{Q} 4$ & $2014 \mathrm{Q} 4$ & $2019 \mathrm{Q} 4$ \\
\hline TFPI & 1.691 & 0.872 & 2.259 \\
FDI & 0.224 & 0.273 & 0.168 \\
FPI & 1.601 & 0.764 & 2.162 \\
Reer & 22.629 & 4.794 & 15.955 \\
R & 2.272 & 1.981 & 2.574 \\
r_NG & 2.305 & 1.985 & 2.628 \\
r_US & 0.226 & 0.040 & 0.319 \\
Oilp & 16.808 & 14.477 & 17.092 \\
RGDP* & 0.012 & 0.009 & 0.014 \\
\hline Notes: (i) TFPI & Total foreign private investment
\end{tabular}

Notes: (i) TFPI is Total foreign private investment; (ii) FDI is Foreign Direct Investment (iii) FPI is Foreign Portfolio Investment (iv) reer is real effective exchange rate $(\mathrm{v}) \mathrm{r}$ is the differential between Nigeria and US 91-day treasury bill rates (v) r_NG is Nigeria's treasury bill rate; and (vi) r_US is US 91-day treasury bill rate; (vii) oilp is crude oil price; (viii) RGDP* is Nigeria's real GDP relative to the US. Source: Author's Computation

The dynamics of capital flow is highly volatile relative to the business cycle. This volatility is driven more by volatility in the dynamics of foreign portfolio investment, though the 
volatility of FDI declined from 0.273 standard deviations between 2010Q1 and 2014Q4 to 0.168 standard deviations between 2015Q1 and 2019Q4. This decline could not offset the quantum leap in the volatility of FPI dynamics. FPI volatility increased from 0.764 standard deviations between 2010Q1 and 2014Q4 to 2.162 standard deviations between 2015Q1 and 2019Q4. This is expected since volatility of currency and interest rate arbitrage are high and increasing, indicating that FPI in Nigeria is relatively more profitable. It is more interesting to note that volatility in interest rate arbitrage is driven more by domestic interest rate which is more volatile relative to foreign interest rate. Volatility in crude oil price is high as expected. The period 2015Q1 to 2019Q4 when oil price is more volatile coincides with period when other macroeconomic fundamentals, including FPI, TFPI, r, reer and RGDP* were as well more volatile supporting the argument that the period 2015Q1 to 2019Q4 is more volatile relative to $2010 \mathrm{Q} 1$ to $2014 \mathrm{Q} 4$.

To explore the influence of arbitrage on capital flow dynamics, Table 3 reports the contemporaneous and lead correlation coefficients of the cyclical components of capital flow, exchange rate, interest rate, crude oil price and relative RGDP.

Table 3: Correlation of Capital flow, Exchange rate, Interest rate and Relative RGDP

\begin{tabular}{llllllc}
\hline Lead & CPF, reer & CPF, r & CPF, r_NG & CPF, r_US & CPF. Oilp & $\begin{array}{l}\text { CPF, } \\
\text { RGDP* }\end{array}$ \\
\hline 0 & 0.38 & 0.10 & 0.08 & -0.21 & 0.28 & -0.35 \\
1 & 0.25 & 0.05 & 0.04 & -0.13 & 0.35 & -0.24 \\
2 & 0.21 & 0.00 & 0.02 & 0.19 & 0.33 & -0.01 \\
3 & 0.17 & -0.01 & 0.03 & 0.51 & 0.39 & 0.01 \\
4 & 0.15 & 0.03 & 0.10 & 0.62 & 0.43 & -0.04 \\
\hline & Notes: CPF is aggregate foreign private investment; $r$ is the difference between Nigeria \\
and US 91-day treasury bill rates (proxy for interest rate differential); reer is the naira's \\
real effective exchange rate; r_NG is Nigeria's 91 day treasury bill rate; r_US is US 91 \\
day treasury bill rate; oilp is crude oil price; RGDP* is the difference between Nigeria \\
and US real GDP (relative GDP) \\
Source: Author's Computation
\end{tabular}

Exchange rate arbitrage has a positive effect on capital flow, indicating that if there is a shock that increases opportunities for arbitrage in exchange rate, foreign investment would flow in, though, the impact would diminish but would last for at least four quarters. Interest rate differential also has a positive relationship with capital flow and is driven more by domestic interest rate as columns 3 and 4 indicate. This supports the economic intuition that a shock that raises domestic interest rate over and above foreign interest rate, in a world of capital 
mobility, would trigger investment inflow since returns on investment are now higher in the domestic economy relative to the rest of the world. However, the effect dissipates and eventually fizzles out in the $3^{\text {rd }}$ quarter. Foreign interest rate showed a negative correlation with capital flow as expected but increases and becomes positive in the $3^{\text {rd }}$ quarter, indicating that a shock that increases foreign interest rate would contemporaneously result in capital outflow and it takes the domestic economy about three quarters to fully adjust and absorb the shock.

Furthermore, push factors such as oil price and US macroeconomic performance have mixed relationship with capital flow to Nigeria. While crude oil price shows positive contemporaneous correlation with capital flow which increases over a four-quarter horizon, the relationship between capital flow and Nigeria's macroeconomic performance relative to the US turns out to be negative. This indicates that global shock that increases crude oil price triggers capital inflow and the effect increases with time, but shock that increases the US economic growth relative to Nigeria causes capital reversals. This is not surprising, since Nigeria is an oil exporting economy and depends largely on oil for foreign exchange earnings and budget financing. Therefore, an increase in oil price does not only increase government revenue but also foreign reserve and results in better macroeconomic fortunes. This increases investors' confidence and because there is more petrodollar to be earned, investors move in with their capital mostly to the oil subsector. Also, the negative relationship between capital flow and relative real GDP is expected. Investors are more interested in returns and it is better guaranteed in a relatively stable and better performing economies thus a relatively better macroeconomic prospects in the US results in capital reversals in Nigeria.

However, correlation measures associations but not impact thus a formal empirical model is specified and estimated to study the impact of interest rate differential and exchange rate movement on the dynamics of Nigeria's international private capital flow.

\section{Data and Methodology}

\subsection{Data}

The data used in this study are quarterly data spanning the period 2010Q1 to 2019Q4. Data were obtained from the Central Bank of Nigeria $(\mathrm{CBN})$ statistics database at http://cenbank.org/cbn-onlinestat/ and the Federal Reserve System (FRS) data download program at https://www.federalreserve.gov/datadownload/. Specifically, data on FDI, FPI, Nigeria's 91-day treasury bill rate, the naira real effective exchange rate and real GDP were ob- 
tained from the CBN statistics database. The US 91-day treasury bill rate was obtained from the FRS data download program.

\subsection{Theoretical Framework}

The model is derived from the IRPT. The IRPT explains how returns on investment in two country's (US and Nigeria) bonds are related. It suggests that IRP is the outcome of profitseeking arbitrage activities of investors. Covered interest parity is represented by equation 1.

$$
\frac{\left(1+i_{\#}\right)}{\left(1+i_{\$}\right)}=\frac{F}{E}
$$

where $i_{\$}$ is interest rate in the US; $i_{\#}$ is the interest rate in Nigeria; $\mathrm{F}$ is the forward exchange rate (naira per dollar) and $\mathrm{E}$ is the spot exchange rate (naira per dollar). The forward exchange rate and interest rates are for assets with the same tenor, for example three months.

The Nigeria investor can earn $\left(1+i_{\#}\right)$ if he invests N1 at home over one period, say a quarter (three months). Alternatively, he can invest in the US by converting naira to dollar at the rate of $1 / E$ dollars and earn $\left(1+i_{\$}\right) / E$ dollars. Since the investor is a resident of Nigeria the returns will be converted to naira, but future spot exchange rates are not known with certainty. The investor can eliminate this uncertainty by covering the dollar investment with a forward contract. By selling $\left(1+i_{\$}\right) / E$ dollars to be received in a future period in the forward market today, the investor has guaranteed a certain naira value of the dollar investment opportunity with a covered return of $\left(1+i_{\#}\right) F / E$ dollars. Thus, the Nigeria investor can earn either $\left(1+i_{\#}\right)$ naira by investing $\mathrm{N} 1$ at home or $\left(1+i_{\#}\right) F / E$ dollars by investing the naira in the US. If interest rates are low, equation 1 can be approximated to (2), derived by subtracting 1 from both sides of (1) as:

$$
\frac{\left(i_{\#}-i_{\$}\right)}{\left(1+i_{\#}\right)}=\frac{(F-E)}{E}
$$

By noting that the denominator on the left-hand side (LHS) is approximately 1 for low interest rates (1) is approximated to (3):

$$
\left(i_{\#}-i_{\$}\right)=\frac{(F-E)}{E}
$$

The smaller $i_{\#}$ is, the better the approximation of (2) by (3). Also note that the right-hand side is simply exchange rate growth (exchange rate movement). Equation 3 indicates that 
the interest rate differential between a comparable Nigerian and US investment is equal to the forward premium or discounted dollar. If there is currency arbitrage, the forward rate would be higher than is required for IRP to hold. Investors will therefore take advantage of the situation, buying the dollar at the spot rate and sell it forward for naira, because the future price of dollar is higher than that implied by the interest parity relation, this results in capital inflow to Nigeria. The continuous capital inflow would cause the spot rate to rise and the forward rate to decline thus bringing the forward premium back in line with the interest rate differential. The interest rates could also move, because the movement of funds into naira investments would tend to depress the naira interest rate, whereas the shift out of dollar investments would tend to raise the dollar interest rate. The mechanism by which capital flow is related to the IRP relation is further elaborated in (4).

$$
C P F=f(i, e)
$$

where $i=\left(i_{\#}-i_{\$}\right)$ is interest rate differential; $e=\frac{(F-E)}{E}$ is exchange rate movement; $f$ is function operator. If there is deviation from parity resulting from higher domestic interest rate, $i$ would be positive and there would be capital inflow. Also, if the deviation from parity is the result of higher forward rates, $e$ would be positive resulting in capital inflow. Conversely, if the deviation results from a higher foreign rate of interest, $i$ would be negative and will lead to capital outflow. Deviations resulting from lower forward rate causes $e$ to be negative and results in capital outflow. Therefore, sustaining capital inflow or reversing outflow holding $e$ constant requires the interest rate differentials to be positive and holding $i$ constant requires exchange rate movement to be positive. However, negative values of $i$ or $e$ when holding the other constant results in capital reversal.

\subsection{Model Specification}

To capture the sensitivity of factors to capital flow regimes, this study adopts the MarkovSwitching Time Varying Transition Probability (MS-TVTP) modelling approach within the IRP framework. The use of the Markov chain in the study of economic and financial time series has been well established in the literature (see Quandt, 1972; Goldfield \& Quandt, 1973; Hamilton, 1990; Filardo, 1994; Diebold, Hahn \& Tay, 1999).

The MS-TVTP model is preferred over other competing models in this study for technical reasons. It provides a way of characterizing regime switching behaviour (asymmetry) in- 
herent in a variable and the persistence of each regime through a stochastic process (Kim and Nelson, 2000; Hamilton, 1990). In addition, MS-TVTP models allow for regime specific volatility measures in a probabilistic manner. Its capacity to handle nonlinear relationships makes it an alternative to autoregressive (AR), moving average (MA) or autoregressive integrated moving average (ARIMA) models, autoregressive conditional heteroskedasticity (ARCH) family of models while its capacity to measure cyclical behaviour such as economic recovery and recession, and capital inflows and outflows makes it superior to the Chow-test and dummy regression approaches to structural breaks. The observed behaviour of capital flows to Nigeria is another factor that informed the use of the MS-TVTP model.

Ning and Zhang (2018) used this approach in their study of China's short-term international capital flow dynamics. They distinguished between inflow and outflow and show that interest rate differential and exchange rate movement are sensitive to inflow and outflow regimes. They however, focused on aggregate capital flow with no exposition on the drivers of the components of international private capital flows to China. To capture the sensitivity of capital type to arbitrage, this study used the components of international private capital flows of FDI and FPI, as well as the aggregated private capital flows.

This study assumes that two regimes (outflow and inflow states) characterizes the dynamics of Nigeria's short-term capital flows and estimate the following MS-TVTP model:

$$
\begin{aligned}
y_{t}= & \mu_{s t}+X_{t} \alpha+Z_{t} \beta_{s t}+\emptyset_{1, s t}\left(y_{t-1}-\mu_{s t-1}-X_{t-1} \alpha-Z_{t-1} \beta_{s t-1}\right) \\
& +\emptyset_{2, s t}\left(y_{t-2}-\mu_{s t-2}-X_{t-2} \alpha-Z_{t-2} \beta_{s t-2}\right)+\varepsilon_{s t}
\end{aligned}
$$

where $y_{t}$ is foreign private capital flow at time $\mathrm{t} ; \mu_{s t}$ is outflow-inflow state dependent intercept, it takes on negative values for outflow and positive values for inflow. $X_{t}$ is a vector of explanatory variables with state invariant coefficients, $\alpha ; Z_{t}$ represents arbitrage (changes in interest rate differential and real effective exchange rate) and $\beta_{s t}$ is the state-dependent coefficient.

If IRP holds, $\beta_{s t}$ would be statistically not different from zero in both states. This means that the interest rate differential is equal to changes in exchange rate (the difference between the spot and future rates), indicating that returns on investment in domestic and foreign assets are equal. Therefore, there is neither interest nor currency arbitrage and investors are indifferent about the choice of where to invest, domestic or foreign assets. But if there is deviation 
from IRP then $\beta_{s t}$ would be statistically different from zero. Positive values imply there is arbitrage in the domestic economy. For interest rate, returns on naira denominated assets are higher than required for IRP to hold and investors would try to take advantage of the higher returns resulting in capital inflow irrespective of the state. For exchange rate movement, this means that the forward rate is too high for parity to hold and investors would buy dollars at the spot rate and sell in the naira forward market to take advantage of the currency arbitrage resulting in capital inflow irrespective of the state. Negative values of $\beta_{s t}$ means arbitrages in the foreign economy. For interest rate differential, this means that the domestic rate is too low for parity to hold, capital flows out in search of higher returns in the foreign economy. For exchange rate, if the forward rate is too low to cover the investment against future returns then investors will move their investment away from the domestic economy.

Therefore, interest rate differential and exchange rate movement can take on either positive or negative sign depending on the presence of arbitrage. Positive (negative) sign if arbitrage is in the domestic (foreign) economy.

$\emptyset_{1, s t}$ is the first Autoregressive (AR) term in state st; $\emptyset_{2, s t}$ is the second AR term in state st; and $\varepsilon_{s t}$ is an i.i.d normal error term with zero mean and regime-dependent variance, $\sigma_{s t}^{2}$. In the model, $\mathrm{X}_{t}$ and $\mathrm{Z}_{t}$ may also contain lags of $y_{t}$. Note that $\mu_{s t-i}$ is the intercept corresponding to the state that the process was in the previous period. That is, $\mu_{s t-1}$ is the conditional mean of capital flow during the outflow state (state 1) and $\mu_{s t-2}$ is the conditional mean during the inflow state (state 2). Similarly, $\beta_{s t-i}$ is the coefficient vector on $Z_{t-i}$ corresponding to the state that the process was in the previous period.

The state variable, $S_{t}$ is governed by a Markov chain transition probability matrix. The probability that $S_{t}=j \in(1,2)$, for a 2 -state representation depends only on the most recent realization and is given as:

$$
P\left(S_{t-1}=i, z_{t}\right)=p_{i j}
$$

The probability that the system moves to state i given that there was a shock in state $j$ is $p_{i j}$. For this study, all possible transitions from one state to the other is presented in the following $2 \times 2$ transition matrix:

$$
P=\left[\begin{array}{ll}
p_{11} & p_{21} \\
p_{12} & p_{22}
\end{array}\right]
$$


Given that the system is in a state of capital outflow, $S_{t-1}$ and there is a shock to the statedependent variable(s), $z_{t}, p_{11}$ measures the probability of remaining in the outflow state, while $p_{12}$ is the probability of transiting to the inflow state. Supposing the system is in the inflow state, $S_{t-2}$ and there is a similar shock $p_{21}$ measures the probability that there would be capital reversal in the following period and $p_{22}$ is the probability that capital inflow would persist the following period.

\subsection{Estimation Procedure}

In examining the dynamics of Nigeria's international private capital flows, estimation begins with data mining. First all the capital flow variables, FDI, FPI and aggregate private capital (CPF) are computed as ratios to the RGDP for scaling purposes. Second, the difference between 91-day treasury bill rates in Nigeria and the United is computed in logarithmic form, following which the logarithm of the naira's real effective exchange rate was computed. Third, the Augmented Dickey-Fuller (ADF) and the Philips-Perron (PP) approaches were used to test for unit root in the variables (see Dickey \& Fuller, 1979; Hamilton, 1989 \& 1994; MacKinnon, 1994 among others). The Akaike information criterion was used for model selection. A confirmatory test was also carried out using the Kwiatkowski, et al. (1992) (or Kwiatkowski-Phillips-Schmidt-Shin (KPSS)) approach due to conflicting results from ADF and PP approaches. The Johansen's cointegration test was then carried out to determine the existence of a long-run relationship among the variables. All the variables were then differenced once based on results from the unit root tests.

\section{Results and Discussion}

The unit root test results are reported in Tables $4 \mathrm{a}$ and $4 \mathrm{~b}$. Table $4 \mathrm{a}$ reports results from the ADF and PP approaches while Table $4 \mathrm{~b}$ contains the confirmatory test results from the KPSS approach. The ADF approach showed all the variables to be stationary after differencing at $1 \%$ critical level but REER became stationary at $10 \%$ critical level after differencing once. The PP results support the ADF results for CPF and REER but indicate that FDI and FPI are level stationary, and $\mathrm{r}$ stationary at first difference and at $1 \%$ critical level. 
Table 4a: Unit root Test Results

\begin{tabular}{|c|c|c|c|c|c|c|}
\hline \multirow[t]{2}{*}{ Variable } & \multicolumn{3}{|c|}{$\begin{array}{l}\text { Augmented Dickey-Fuller Test Statis- } \\
\text { tic }\end{array}$} & \multicolumn{3}{|c|}{ Philips-Perron Test Statistic } \\
\hline & Level & $1^{s t}$ Diff. & $\sim \mathrm{I}(\mathrm{d})$ & Level & $1^{\text {st }}$ Diff. & $\sim \mathrm{I}(\mathrm{d})$ \\
\hline \multirow[t]{2}{*}{ FPI } & -1.740 & $-3.702 * * *$ & $\mathrm{I}(1)$ & $-4.412 * * *$ & $-8.782 * * *$ & $\mathrm{I}(0)$ \\
\hline & {$[0.4106]$} & {$[0.0041]$} & & {$[0.0021]$} & {$[0.0000]$} & \\
\hline \multirow[t]{2}{*}{ FDI } & -1.073 & $-5.962 * * *$ & $\mathrm{I}(1)$ & $-5.012 * * *$ & $-11.648 * * *$ & $\mathrm{I}(0)$ \\
\hline & {$[0.7255]$} & {$[0.0000]$} & & {$[0.0002]$} & {$[0.0000]$} & \\
\hline \multirow[t]{2}{*}{$\mathrm{CPF}$} & -1.182 & $-3.626 * * *$ & $\mathrm{I}(1)$ & -2.737 & $-5.683 * * *$ & $\mathrm{I}(1)$ \\
\hline & {$[0.6812]$} & {$[0.0053]$} & & {$[0.2212]$} & {$[0.0000]$} & \\
\hline \multirow[t]{2}{*}{$\mathrm{r}$} & -2.145 & $-2.804 *$ & $\mathrm{I}(1)$ & -1.901 & $-5.526 * * *$ & $\mathrm{I}(1)$ \\
\hline & [0.2269] & {$[0.0577]$} & & {$[0.6541]$} & {$[0.0000]$} & \\
\hline \multirow[t]{2}{*}{ reer } & -1.872 & $-5.629 * * *$ & $\mathrm{I}(1)$ & -1.865 & $-5.616 * * *$ & $\mathrm{I}(1)$ \\
\hline & {$[0.3454]$} & {$[0.0000]$} & & {$[0.3487]$} & {$[0.0000]$} & \\
\hline $\begin{array}{l}5 \% \text { critical } \\
\text { value }\end{array}$ & -2.972 & -2.975 & & -3.544 & -3.548 & \\
\hline
\end{tabular}

The results in Table $4 \mathrm{~b}$ indicate that FPI, FDI, CPF and $\mathrm{r}$ are stationary around deterministic trend since the null of trend stationarity could not be rejected at the $5 \%$ critical level, while REER is nonstationary. When the test is carried out without trend the null of stationarity at level is rejected for all the variables. However, the null could not be rejected after differencing once indicating that the variables are integrated of order one, I(1) that is, stationarity is achieved after differencing once. The cointegration test results are shown in Table 5.

Table 5 has three panels, the first reports results for the aggregate capital flow model while the second and third report results for the FDI and FPI models, respectively. The null of no cointegrating equation could not be rejected in all the models as the trace statistic for the corresponding 0 ranks were all less than the $5 \%$ critical values. This study concludes that the variables in each of the models have no long-run relationship. The absence of cointegration coupled with I(1) property of the series satisfies the condition for estimating short-run models. All the variables are therefore used at first difference in the model. 
Table 4b: KPSS Confirmatory Unit root Test Results (lags 3)

\begin{tabular}{lllllll}
\hline Variable & Trend & \multicolumn{5}{c}{ No Trend } \\
\hline FPI & Level & $1^{\text {st }}$ Diff. & $\sim \mathrm{I}(\mathrm{d})$ & Level & $1^{\text {st }}$ Diff. & $\sim \mathrm{I}(\mathrm{d})$ \\
FDI & 0.0686 & 0.0677 & $\mathrm{I}(0)$ & $0.512^{* *}$ & 0.122 & $\mathrm{I}(1)$ \\
CPF & 0.085 & 0.0392 & $\mathrm{I}(0)$ & $0.654^{* *}$ & 0.0412 & $\mathrm{I}(1)$ \\
$\mathrm{R}$ & 0.0773 & 0.0654 & $\mathrm{I}(0)$ & $0.544^{* *}$ & 0.1300 & $\mathrm{I}(1)$ \\
REER & 0.139 & 0.0733 & $\mathrm{I}(0)$ & $0.538^{* *}$ & 0.364 & $\mathrm{I}(1)$ \\
$5 \% \quad$ critical & $0.189 * *$ & 0.121 & $\mathrm{I}(1)$ & $0.634^{* *}$ & 0.137 & $\mathrm{I}(1)$ \\
value & 0.146 & & & 0.463 & &
\end{tabular}

Notes: FPI is Foreign Portfolio Investment; FDI is Foreign Direct Investment; CPF is aggregate foreign private investment; $r$ is the difference between Nigeria and US 91-day treasury bill rates proxy for interest rate differential; reer is the naira's real effective exchange rate; [ ] Mackinnon (1994) approximate probability value for tau; and ***(**)* indicate significance at $1 \%(5 \%)$ $10 \%$.

Table 5: Jonahsen's Rank test for Cointegration

\begin{tabular}{llll}
\hline Maximum rank & Eigen value & Trace statistic & 5\% critical value \\
\hline & \multicolumn{2}{l}{ Aggregate capital flow model } \\
0 & - & 23.4302 & 29.68 \\
1 & 0.53545 & 14.2962 & 15.41 \\
2 & 0.23927 & 3.9040 & 3.76 \\
3 & 0.09764 & - & - \\
& FDI model & & \\
0 & - & 14.4922 & 29.68 \\
1 & 0.44891 & 11.8495 & 15.41 \\
2 & 0.21155 & 2.88173 & 3.76 \\
3 & 0.07146 & & \\
& FPI model & & 29.68 \\
0 & - & 25.2652 & 15.41 \\
1 & 0.55013 & 14.9112 & 3.76 \\
2 & 0.24794 & 4.0837 & \\
3 & 0.10189 & & \\
\hline
\end{tabular}

Source: Author's Computation

Following the unit root and cointegration tests, variants of the Markov switching probability model (MSPM) were estimated and reported in Tables 6 and 7 for the aggregate capital flow and disaggregated capital flow models, respectively. Table 6 Column 1 reports the benchmark model, that is, the fixed transition probability (FTP) model with state-invariant information variables and AR terms; column 2 reports a time varying transition probability (TVTP) model with state-invariant information variables and AR terms and column 3 reports a TVTP model with state-dependent information variables and state-invariant AR terms. The estimates in Table 6 describe the dynamic regime-switching behaviour of Nigeria's aggregate international private capital flows between 2010Q1 and 2019Q4. The regime-dependent intercepts 
are statistically not significant, though, presents evidence supporting the assumption that two distinct regimes characterize the dynamics of Nigeria's international private capital flows since they show opposite signs. The point estimate in regime 1 is negative thus is labeled outflow regime and positive in regime 2 therefore is labeled inflow regime.

However, the estimates of the information criteria, AIC, SBIC and HQIC indicate that the FTP model is weak in describing the behaviour of Nigeria's international private capital flows. It turns out that all the time-independent coefficients are statistically not significant. Improvement of the estimates is achieved in the TVTP model in column 2 but deteriorate in column 3, showing that the model in column 2 provides a best fit for the data. Column 2 of Table 6 reports the estimates of interest rates and exchange rates used as state-independent information variables.

The study also estimated disaggregated models with FPI and FDI each as the dependent variables with results shown in Table 7. Interest rate differentials and changes in real effective exchange rate are state-dependent information variables together with the AR terms. The results in Table 7 describes the dynamic characteristics of Nigeria's foreign portfolio investment and foreign direct investment flows. The intercept with negative sign represents the outflow regime and the one with positive sign, the inflow regime, both of which are statistically significant. Conditioned on interest rate differential and movement in the real exchange rate the mean international private capital flows given that the system was in the outflow state in the previous quarter is $2.42 \%$ of real GDP and $0.15 \%$ given that it was in the inflow state (Table 6). This is important for policymakers since it shows that the magnitude of outflow resulting from a shock is larger than the magnitude of inflow resulting from opposite shock of equal magnitude. This result however masks the peculiarities of each type of capital flow as the FPI and FDI models suggest that FPI outflows are larger than inflows but FDI inflows are marginally larger than outflows. 
Table 6: Determinants of Nigeria's Aggregate International Capital Flow Dynamics

\begin{tabular}{|c|c|c|c|}
\hline & $\begin{array}{l}\text { Fixed Transition Probabil- } \\
\text { ity (FTP) Model }\end{array}$ & $\begin{array}{l}\text { Time Vary } \\
\text { ity (TVTP }\end{array}$ & $\begin{array}{l}\text { ansition Probabil- } \\
\text { el }\end{array}$ \\
\hline & $\Delta \mathrm{CPF}$ & $\Delta \mathrm{CPF}$ A1 & $\triangle \mathrm{CPF}$ A2 \\
\hline & State-Invariant Coefficients & & \\
\hline$\Delta \mathrm{r}$ & -0.051 & -0.057 & - \\
\hline & $(0.066)$ & $(0.040)$ & \\
\hline & {$[0.442]$} & {$[0.158]$} & \\
\hline$\Delta$ reer & 2.816 & 1.948 & - \\
\hline & $(2.069)$ & $(1.409)$ & \\
\hline & {$[0.174]$} & {$[0.167]$} & \\
\hline $\operatorname{AR}(1)$ & -0.168 & $-0.470 * * *$ & -0.194 \\
\hline & $(0.164)$ & $(0.045)$ & $(0.184)$ \\
\hline & {$[0.304]$} & {$[0.000]$} & [0.292] \\
\hline $\operatorname{AR}(2)$ & -0.183 & $-0.461 * * *$ & -0.230 \\
\hline & $(0.174)$ & $(0.054)$ & $(0.202)$ \\
\hline & {$[0.291]$} & {$[0.000]$} & {$[0.256]$} \\
\hline & State 1: Capital Outflow State & & \\
\hline Constant & -0.212 & $-2.416 * * *$ & 1.375 \\
\hline & $(1.395)$ & $(0.626)$ & $(7.792)$ \\
\hline & {$[0.879]$} & {$[0.000]$} & {$[0.860]$} \\
\hline$\Delta \mathrm{r}$ & - & - & 0.812 \\
\hline & & & $(1.783)$ \\
\hline & & & [0.649] \\
\hline$\Delta$ reer & - & - & 53.373 \\
\hline & & & $(247.321)$ \\
\hline & & & {$[0.829]$} \\
\hline & State 2: Capital Inflow State & & \\
\hline Constant & 0.026 & $0.149 * *$ & 0.028 \\
\hline & $(0.105)$ & $(0.067)$ & $(0.0998)$ \\
\hline & [0.803] & {$[0.026]$} & {$[0.779]$} \\
\hline$\Delta \mathrm{r}$ & - & - & -0.054 \\
\hline & & & $(0.065)$ \\
\hline & & & {$[0.405]$} \\
\hline$\Delta$ reer & - & - & 2.823 \\
\hline & & & $(2.067)$ \\
\hline & & & {$[0.172]$} \\
\hline
\end{tabular}


Table 6 contd.: Determinants of Nigeria's Aggregate International Capital Flow Dynamics

\begin{tabular}{llll}
\hline & $\begin{array}{l}\text { Fixed Transition Probabil- } \\
\text { ity (FTP) Model }\end{array}$ & \multicolumn{2}{c}{ Time Varying Transition Probabil- } \\
ity (TVTP) Model
\end{tabular}


Table 7: Determinants of Disaggregated Nigeria's International Capital Flows Dynamics

\begin{tabular}{|c|c|c|c|c|}
\hline & $\Delta \mathrm{FPI}$ & $\Delta \mathrm{FDI}$ & $\Delta \mathrm{FPI}$ & $\Delta \mathrm{FDI}$ \\
\hline & Outflow State & & Inflow State & \\
\hline Constant & $-0.949 * * *$ & $-0.325 * * *$ & $0.201 * * *$ & $0.336^{* * *}$ \\
\hline & $(0.095)$ & (0.019) & $(0.031)$ & $(0.033)$ \\
\hline & {$[0.000]$} & {$[0.000]$} & [0.000] & [0.000] \\
\hline$\Delta \mathrm{r}$ & $0.073 * *$ & -0.002 & $-0.354 * * *$ & 0.002 \\
\hline & $(0.032)$ & $(0.007)$ & $(0.035)$ & $(0.008)$ \\
\hline & {$[0.022]$} & {$[0.716]$} & {$[0.000]$} & [0.791] \\
\hline$\Delta$ reer & $-26.321 * * *$ & -0.266 & $5.047 * * *$ & $1.883 * * *$ \\
\hline & (3.188) & $(0.475)$ & (0.949) & $(0.192)$ \\
\hline & [0.000] & {$[0.574]$} & {$[0.000]$} & [0.000] \\
\hline $\mathrm{AR}(1)$ & $-1.226 * * *$ & $-0.685 * * *$ & $-0.248 * * *$ & $0.860 * * *$ \\
\hline & $(0.086)$ & $(0.097)$ & $(0.054)$ & $(0.138)$ \\
\hline & $(0.000)$ & {$[0.000]$} & {$[0.000]$} & {$[0.000]$} \\
\hline $\operatorname{AR}(2)$ & $-2.306 * * *$ & $-0.846 * * *$ & $-0.157 * *$ & $0.817 * * *$ \\
\hline & $(0.079)$ & $(0.130)$ & $(0.068)$ & $(0.125)$ \\
\hline & {$[0.000]$} & {$[0.000]$} & {$[0.022]$} & [0.000] \\
\hline $\operatorname{AR}(3)$ & $-1.098 * * *$ & $-0.664 * * *$ & $-0.256 * *$ & $1.291 * * *$ \\
\hline & $(0.074)$ & (0.104) & $(0.111)$ & $(0.142)$ \\
\hline & {$[0.000]$} & {$[0.000]$} & {$[0.021]$} & {$[0.000]$} \\
\hline $\mathrm{AR}(4)$ & $-0.949 * * *$ & $-0.325 * * *$ & $0.187 *$ & $1.232 * * *$ \\
\hline & $(0.095)$ & (0.019) & $(0.096)$ & $(0.127)$ \\
\hline & {$[0.000]$} & {$[0.000]$} & {$[0.050]$} & {$[0.000]$} \\
\hline & & FPI Model & & FDI Model \\
\hline State inva & nce & $0.357(0.043)$ & & $0.106(0.013)$ \\
\hline Transition & ties & & & \\
\hline $\mathrm{P} 11$ & & $0.1622(0.105)$ & & 0.1299 \\
\hline & & & & $(0.086)$ \\
\hline P12 & & 0.8378 & & 0.8701 \\
\hline & & $(0.105)$ & & $(0.086)$ \\
\hline $\mathrm{P} 21$ & & 0.4417 & & 0.5880 \\
\hline & & $(0.102)$ & & $(0.106)$ \\
\hline $\mathrm{P} 22$ & & 0.5583 & & 0.4120 \\
\hline & & $(0.102)$ & & $(0.106)$ \\
\hline Chi-squar & & $90.70 * * *$ & & $189.18 * * *$ \\
\hline & & {$[0.0000]$} & & {$[0.0000]$} \\
\hline
\end{tabular}


Table 7 contd.: Determinants of Disaggregated Nigeria's International Capital Flows Dynamics

\begin{tabular}{lll}
\hline EDO & $1.194(0.149)$ & 1.149 \\
EDI & $2.264(0.524)$ & $(0.113)$ \\
& & 1.701 \\
AIC & 3.0254 & $0.306)$ \\
HQIC & 3.2862 & 0.5349 \\
BIC & 3.7809 & 0.7957 \\
\hline
\end{tabular}

$\triangle F D I$ is change in foreign direct investment; $\triangle F P I$ is change in foreign portfolio investment; EDO is expected duration in state 1 that is, outflow state; EDI = expected duration in state 2, that is, inflow state; Chi-square test is Wald chisquare test statistics of the existence of a single state; Sigma is state-invariant variance; Standard errors ( ) and p-values [ ].

The marginal difference between FDI inflows and outflows indicate the diminishing importance of FDI to the Nigerian economy in recent years resulting from declining number of new investments. The FPI and FDI models suggest $0.95 \%$ and $0.33 \%$ outflows and $0.2 \%$ and $0.34 \%$ inflows, respectively (Table 7). Interestingly, the regime-dependent variances reveal that the outflow state is highly volatile relative to the inflow state, with FPI found to be more volatile (see Table 7).

However, estimates of the transition probability shows that the outflow states in the aggregate and disaggregated models are nonpersistent, supporting the results of the AR terms in each model with smaller transition probabilities, which means high probability to return to the inflow state if it was in the outflow state the previous period. It is also interesting to see that the inflow state is persistent in the aggregate and the FPI models but not in the FDI model, suggesting that, 87 times out of 100 there would be aggregate capital inflows in the current period given that there was inflow the previous period and 56 times out of 100 there would be portfolio inflows in the current period given that there was inflow in the previous period. The implication is that the likelihood of aggregate capital and FPI reversal if there is inflow is slim. The estimates of the expected duration in each state supports these results. The Expected duration in the outflow state is 1 quarter each for the aggregate, FPI and FDI models and about 8 quarters in the inflow state for the aggregate model and 2 quarters each for FPI and FDI. It turns out that the persistence of both the outflows and inflows are statistically significant in the aggregate model. This also supports results from the AR terms which indicates that negative shocks can last for at most two quarters. The outflow state is statistically significant for FDI but not FPI, and the inflow state is significant for both FDI and FPI. Interest rate 
differential turns out to be negative and statistically not significant in the aggregate model. This is in line with IRPT, indicating that there is no deviation from parity, and that there are no opportunities for positive interest arbitrage in Nigeria relative to the rest of the world.

However, the FPI model suggests otherwise. The coefficient on interest rate in the outflow and inflow states show opposite signs and are statistically significant therefore, the IRPT does not hold, that is, there are deviations from parity. With real exchange rate unchanged, increase in domestic interest rate relative to foreign interest rate induces inflows of FPI provided the system is in the outflow state. This implies that there are opportunities for interest rate arbitrage in Nigeria. When returns on Nigeria's tradable securities increase relative to foreign securities, investors move to Nigeria to invest in domestic securities thus reversing capital outflow. This is intuitively plausible since holding real exchange rate constant means that the value of the naira is unchanged thus an increase in interest rate differential would represent higher returns for investments. Negative interest differential in the inflow state means that deviations from parity arises from higher returns in foreign assets. A shock that increases the foreign interest rate relative to the domestic interest rate results in capital reversal provided the system is in the inflow state, because it becomes more beneficial to invest in foreign securities. For FDI, interest rate differential is negative in the outflow state and positive in the inflow state but are both statistically not significant. This is expected since FDI is a longterm investment and short-term gains are not the overriding interest. Therefore, in the case of FDI there are no deviations from parity and interest rate arbitrage is absent.

A key inference from this study is that interest rate differential is not important in explaining the dynamics of aggregate capital and FDI flows in Nigeria, but in the FPI market there are opportunities for interest rate arbitrage. The aggregate model supports the position of Dooley (1988), which states that interest rate differential is not a factor responsible for international capital flight in developing countries. Wang and He (2007), also showed that interest rate differentials account for very little in the dynamics of China's short-term international capital flows.

On currency arbitrage, the real effective exchange rate is positive as expected in the aggregate model but state-invariant and statistically not significant. This suggests that there is no deviation from parity and that there is no currency arbitrage for investors to benefit from both in Nigeria and abroad. In the FPI model, real effective exchange rate is negative and statistically 
significant in the outflow state (Table 7), indicating deviations from parity and the existence of currency arbitrage. An appreciation of the real exchange rate indicates that the value of the domestic currency (the naira) has depreciated. Under this situation with the interest rate differential remaining constant there would be currency arbitrage in the domestic economy as a dollar can now acquire more naira which in turn purchases more domestic securities. Thus, the demand for naira by investors will increase to purchase more naira denominated assets and thus earn more profit thereby reversing capital outflow in the following period. This is consistent with previous studies suggesting that currency arbitrage is the main driver of the dynamic behaviour of short-term international capital flows (see Su \& Zhang, 2010; Fang et al., 2012; Cheung et al., 2016).

Real exchange rate turns out to be positive and statistically significant in the inflow state, indicating that shocks that cause real exchange rate appreciation often perpetuate FPI inflows, which supports economic intuition. Real exchange rate appreciation implies depreciation in the value of the domestic currency. With interest rate differential remaining constant the opportunity for currency arbitrage is created and so FPI inflow would continue in the following period. In the FDI model in Table 7 real effective exchange rate is negative in the outflow state suggesting that real exchange rate appreciation reverses FDI outflow, but it turns out to be statistically not significant indicating the existence of parity and that there are no opportunities for arbitrage in the FDI market. In the inflow state, real effective exchange rate is positive and statistically significant suggesting that real exchange rate appreciation perpetuates FDI inflow. This is surprising since exchange rate appreciation implies that domestic goods are more expensive relative to foreign goods. Investors would thus prefer to invest in other countries and export to Nigeria hence a decline in the rate of FDI inflow. This was, however, not the case. Thus, the continuous inflow of FDI in the face of an appreciation in real exchange rate could be attributable to other factors not considered in this study. In addition, this result could be attributable to the bureaucratic difficulties and other considerations associated with FDI reversal.

In summary, this study deduced that there is no currency arbitrage in the aggregate capital market but when the components of FDI and FPI are examined separately, currency arbitrage is observed. Changes in real exchange rate is significant in explaining outflow and inflow in FPI, and inflow in FDI, but neutral to aggregate capital flow. These findings are unique to 
this study since previous studies for Nigeria did not account for capital inflows and outflows separately, while studies from the rest of the world that considers capital inflows and outflows did not account for the determinants of the individual components of capital flows.

The aggregate model in column 2 of Table 6, and the FPI and FDI models in Table 7 are all adequate in describing the data as the likelihood ratio chi-square values are all statistically significant at $1 \%$ level of significance.

\section{Conclusion and Policy Recommendation}

This study examined the determinants of international private capital flows to Nigeria. It measured international private capital flows as changes in the sum of net FDI and FPI, and interest rate differentials as the difference between the 91-day Treasury Bill rates for Nigeria and the US. Empirical results suggest that Nigeria's aggregate international private capital flows is not sensitive to movements in the exchange rate and changes in the interest rate differentials but, disaggregating capital flows into FDI and FPI reveals otherwise. Foreign investors in Nigerian securities do harness opportunities in interest rate and currency movements. The speculative activities of investors resulted in the high level of volatility in the exchange rate market, especially within the period 2015Q1 to 2019Q4 which is characterized by massive capital reversals.

Therefore, this study concludes that an increase in interest rate differentials and real exchange rate appreciation are key factors in the dynamics of FPI inflows and reversals from Nigeria, while real exchange rate appreciation perpetuates FDI inflows. These findings are, however, masked when aggregate capital flow is analyzed rather than its individual components. Using aggregate capital indicates that there are no deviations from parity therefore suggesting wrongly that there is no interest rate nor currency arbitrage in Nigerian securities.

The study, therefore, recommends that the CBN should focus on exchange rate stabilising policies, so as not only to discourage FPI reversal but to also enhance FDI inflow. This can be done by putting in place foreign reserves accretion measures to boost the ability of the CBN to defend the Naira. Hence, the new policy initiative on remittances is commendable as it could boost external reserves. 


\section{References}

Adegboye, B. F., Adesina, F. T., Ojeka, A. S., Akinjare, A. V. \& Olokoyo, O. F. (2020). Foreign direct investment, dual gap model and economic development in sub-Saharan Africa. Cogent Social Sciences, 6(1), 1743138: http://doi.org/10.1080/23311886.2020.1743138

Adejumo, A. O. \& Ikhide, S. I. (2019). Effects of remittance inflows on exchange rates in Nigeria. Journal of Developing Areas, 53(1), 1-15.

Adewuyi, A. O. \& Ogebe, J. O. (2019). The validity of uncovered interest parity: Evidence from African members and non-member of the organization of petroleum exporting countries (OPEC). Economic Modelling, 82: 229-249.

Aitken, B. J., \& Harrison, A. E. (1994). Do domestic firms benefit from foreign direct investment? Evidence from panel data. World Bank Policy Research Working Paper No. 1248 .

Ames, M., Bagnarosa, G. \& Peters, G.W. (2017). Violations of uncovered interest rate parity and international exchange rate dependences. Journal of International Money and Finance, 73 (part A), 162-187. doi: http:// dx.doi.org/10.1016/j.jimonfin.2017.01.002

Amuedo-Dorantes, C (2014). The good and the bad in remittance flows. IZA World of Labour doi: 10.15185/izawol.97

Barry, F. \& Bradley, J. (1997). FDI and trade: the irish host-country experience. The Economic Journal, 107: 1798-811.

Basu, P., Chakraborty, C. \& Reagle, D. (2003). Liberalization, FDI, and growth in developing countries: A panel cointegration approach. Economic Inquiry, 41: 510-16.

Blomström, M., Kokko, A. \& Zejan, M. (1994). Host country competition, labor skills, and technology transfer by multinationals. Review of World Economics, 130: 521-33.

Bogdan, T. (2016). Determinants of capital flows to emerging market economy: A case of ukraine. Transformations in Business \& Economics, 15[1(37)], 127-146.

Bosworth, B. P., Collins, S. M. \& Reinhart, C. M. (1999). Capital flows to developing economies: implications for saving and investment. Brookings Papers on Economic Activity, 1: 143-80.

Brana, S. \& Lahet, D. (2010). Determinants of capital inflows into Asia: The relevance of contagion effects as push factors. Emerging Markets Review, 11: 273-284

Buckley, P. J., Clegg, J., Wang, C. \& Cross, A (2002). FDI, regional differences and economic growth: Panel data evidence from China. Transnational Corporation, 11: 1-28. 
Byrne, J. P. \& Fiess, N. (2015). International capital flows to emerging markets: national and global determinants. Journal of International Money and Finance. http://dx.doi.org/doi:10.1016/j.jimonfin.2015.11.005.

Calvo, G. A., Leiderman, L. \& Reinhart, C. M. (1993). Capital inflows and real exchange rate appreciation in latin america: the role of external factors. Staff Papers (International Monetary Fund), 40(1), 108-151.

Caporale, G. M., Donadelli, M. \& Varani, A. (2015). International capital markets structure, preferences and puzzles: A "US-China World". Journal of International Financial Markets, Institutions and Money, 36(C), 85-99.

Caves, R. E. (1974). Multinational firms, competition, and productivity in host-country markets. Economica, 41: 176-93.

CBN (2020). Central Bank of Nigeria database available at http://cenbank.org/cbn-onlinestat/ accessed on April, 5.

Chenery, H. B. \& Stout, A. (1966). Foreign assistance and economic development. American Economic Review 55: 679 - 733.

Cheung, Y. W., Sven, S. \& Frank, W. (2016). China's capital flight: Pre-and post-crisis experiences. Journal of International Money and Finance, 66: 88-112.

Çulha, A. A. (2006). A structural VAR analysis of the determinants of capital flows into Turkey. Central Bank Review 2: 11-35.

Dickey, D. A., \& Fuller, W. A. (1979). Distribution of the estimators for autoregressive time series with a unit root. Journal of the American Statistical Association, 74: 427-431.

Diebold, F. X., Hahn, J., \& Tay, A. S. (1999). Multivariate density forecast evaluation and calibration in financial risk management: High-frequency returns on foreign exchange. Review of Economics and Statistics, 81: 661-673.

Djordjevic, S., Ivanovic, Z. \& Bogdan, A. (2015). Direct foreign investments and the lack of positive effects on the economy. UTMS Journal of Economics, 6: 197-208.

Dooley, M. P. (1988). Capital flight: A response to differences in financial risks. Staff Papers, 35: 422-436.

Drakos, A. A., Kouretas, P. G., Stavroyiannis, S. \& Zarangas, L. (2017). Is the FeldsteinHorioka puzzle still with us? National saving-investment dynamics and international capital mobility: A panel data analysis across EU member countries.

Enisan, A. A. (2017). Determinants of foreign direct investment in Nigeria. Review of Innovation and Competitiveness, 3 (1), 21-48 
Essien, E. A. \& Onwioduokit, E. A. (1999). Capital flows to Nigeria: Issues and determinants. CBN Economic \& Financial Review, 37(1): 1 - 20

Fang, G. M., Pei, P. \& Zhang, Y. H. (2012). International speculative capital inflows in China: Motivation and impacts. Journal of Financial Research, 379: 65-77 [in Chinese].

Filardo, A. J. (1994). Business-cycle phases and their transitional dynamics. Journal of Business \& Economic Statistics, 12: 299-308.

Feldstein, M. (1983). Domestic saving and international capital movements in the long run and the short run. European Economic Review, 21: 129-151.

Feldstein, M. \& Horioka, C. (1980). Domestic saving and international capital flows. Economic Journal, 9: 14-329.

Förster, M., Jorra, M. \& Tillmann, P. (2012). The dynamics of international capital flows: Results from a dynamic hierarchical factor model. MAGKS Joint Discussion Paper Series in Economics, No. 21-2012, Philipps-University Marburg

Georgoutsos, D. A. \& Kouretas, G. P. (2016). Interest parity, cointegration, and the term structure: Testing in an integrated framework. International Review of Financial Analysis, 46: 281-294

Glauco, D. V. \& Kyaw, K. S. (2008a). Determinants of FDI and portfolio flows to developing countries: A panel cointegration analysis. European Journal of Economics, Finance and Administrative Sciences, 13: 161 - 168

Glauco, D. V. \& Kyaw, K. S. (2008b). Determinants of capital flows to developing countries: a structural VAR analysis. Journal of Economic Studies, 35(4), 304-322

Goldfield, S. M. \& Quandt, R. E. (1973). A Markov model for switching regressions. Journal of Econometrics 1: 3-15.

Grzegorz, T., Brzozowski, M. \& Śliwiński, P. (2017). Determinants of capital flows to emerging and advanced economies between 1990 and 2011. Port Economic Journal. DOI: $10.1007 / \mathrm{s} 10258-016-0126-5$

Hamilton, J. D. (1989). A new approach to the economic analysis of nonstationary time series and the business cycle. Econometrica, 57: 357-384.

Hamilton, J. D. (1990). Analysis of time series subject to changes in regime. Journal of Econometrics 45: 39-70.

Hamilton, J. D. (1994). Time series analysis. Princeton, NJ: Princeton University Press.

Ibrahim, W. \& Omoniyi, B. (2011). Determinants of foreign direct investment in Nigeria: Political factor effects revisited. MPRA Paper No. 59429. 
Ismailov, A. \& Rossi, B. (2018). Uncertainty and deviations from uncovered interest rate parity. Journal of International Money and Finance, 88: 242-259

Keynes, J. M. (1923). A tract on monetary reform, London: Macmillan.

Khurshid, A., Kedong, Y., Calin, A. C. \& Khan, K. (2017). Effects of workers' remittances on exchange rate volatility and exports dynamics: New evidence from pakistan. The Romanian Economic Journal, 63, 29-52

Kim, S., Kim, S. H. \& Wang, Y. (2007). Saving, investment and international capital mobility in East Asia. Japan and the World Economy, 19(2), 279-291.

Kim, C. J. \& Nelson, C. R. (2000). State-space models with regime switching. MIT Press, Cambridge, Massachusetts London, England.

Konings, J. (2001). The effects of foreign direct investment on domestic firms. Econ. Transit. 9: 619-33.

Kose, M. A., Prasad, E. S. \& Terrones, M. E. (2009). Does financial globalization promote risk sharing? Journal of Development Economics, 89: 258-70.

Kwiatkowski, D., Phillips, P. C. B., Schmidt, P. \& Shin, Y. (1992). Testing the null hypothesis of stationarity against the alternative of a unit root. Journal of Econometrics, $54: 159-178$

Lartey, E. K. K. (2017). Exchange rate flexibility and the effect of remittances on economic growth. Review of Development Economics, 21(1), 103-125.

Leonard, N. A. (2018). The impact of exchange rate on foreign private investment in Nigeria. Asian Finance \& Banking Review, 2(2), 19-32

Levich, R. M. (2011). Evidence on financial globalization and crises: Interest rate parity. Stern School of Business, Unpublished.

Lothian, J. R. (2016). Uncovered interest parity: The long and the short of it. Journal of Empirical Finance, 36: 1-7

MacKinnon, J. G. (1994). Approximate asymptotic distribution functions for unit-root and cointegration tests. Journal of Business \& Economic Statistics 12: 167-176.

Maghori, E. (2014). Determinants of foreign direct investment in nigeria: evidence from cointegration and error correction modeling. International Journal of Business and Social Science 5(6), 215-224.

Mansfield, E. \& Romeo, A. (1980). Technology transfer to overseas subsidiaries by USbased firms. Quarterly Journal of Economics, 95: 737-50. 
Moreno, R. (1998). What caused East Asia's financial crisis? Economic Research, Economic Letters No. 24

Ning, Y. \& Zhang, L. (2018). Modeling dynamics of short-term international capital flows in China: A Markov regime switching approach. North America Journal of Economics and Finance, https://doi.org/10.1016/j.najef.2018.01.002

Nwokoye, E. S. \& Oniore, J. O. (2017). Impact of monetary policy on capital inflows in Nigeria. Business, Management and Economic Review, 3(10), 192-200

Nwosa, P. I. \& Adeleke, O. (2017). Determinants of FDI and FPI volatility: An E-GARCH approach. CBN Journal of Applied Statistics 8(2), 47- 67.

Obida, G. W. \& Abu, N. (2010). Determinants of foreign direct investment in Nigeria: An empirical analysis. Global Journal of Human Social Science 10(1 Ver 1.0), 26-34.

Obstfeld, M. (1981). Macroeconomic policy, exchange rate dynamics, and optimal asset accumulation. Journal of Political Economy, 85: 1142-1161.

Okereke, E. \& Ebulison, N. (2016). Determinants of foreign direct investment inflows in Nigeria: An empirical analysis. Available at http://dx.doi.org/10.2139/ssrn.2756975

Park, C. \& Park, S. (2017). Can monetary policy cause the uncovered interest parity puzzle? Japan and the World Economy, 41: 34-44

Quandt, R. E. (1972). A new approach to estimating switching regressions. Journal of the American Statistical Association, 67: 306-310.

Schoors, K. \& Tol, B. V. (2002). Foreign direct investment spillovers within and between sectors: Evidence from hungarian data.

Available at http://wps-feb.ugent.be/Papers/wp_02_157.pdf (accessed on 12 January 2020).

Singer, D. A. (2010). Migrant remittances and exchange rate regimes in the developing world. American Political Science Review, 104(2), 307-323.

Su, D. S., \& Zhang, Z. G. (2010). Quadruplex arbitrage model and short-term international capital flow. Finance and Economics, 269: 17-24.

Taylor, M. P. \& Sarno, L. (1997). Capital flows to developing countries: Long- and shortterm determinants. World Bank Economic Review, 11(3), 451-470

Teall, J. L. (2018). Financial trading and investing. $2^{\text {nd }}$ edition UK: Candice Janco, Elsevier Inc.

Thirlwall, P. A. (1976). Financing economic development. London: The MacMillan Press Ltd. 
Vasilyev, D., Busygin, V. \& Busygin, S. (2017). Testing and interpreting uncovered interest parity in Russia. Russian Journal of Economics, 3: 158-173.

Wang, S. H. \& He, F. (2007). On China's short-term international capital flows: Current situation, flow path and influencing factors. The Journal of World Economy, 7: 12-19.

Wang, K. H., Su, C. W. \& Tao, R. (2019). Time-varying character for short-term capital flow from the interest rate aspect in China. Economic Research-Ekonomska Istrazivanja, 32(1): 2761-2779 [in Chinese]

World Bank (2020). Migration and development brief 32: COVID-19 crisis through a migration lens. World Bank, Washington, DC.

World Bank (2019a). Migration and remittances: Recent developments and outlook. Migration and Development Brief, No. 31. World Bank, Washington, DC.

World Bank (2019b). Data release: Remittances to low- and middle-income countries on track to reach $\$ 551$ billion in 2019 and $\$ 597$ billion by 2021. People on the Move blog.

World Bank (2019c). Leveraging Economic Migration for development: A briefing for the world bank board (English). Washington, D.C.: World Bank Group.

World Bank (2018a). Migration and remittances: Recent developments and outlook. Migration and Development Brief, No. 30, December 2018. World Bank, Washington, DC.

World Bank (2018b). Migration and remittances: Recent developments and outlook. Migration and Development Brief, No. 29. World Bank, Washington, DC.

World Bank (2016). Migration and remittances factbook 2016. World Bank, Washington, D.C.

Yamazawa, I. (1998). The Asian economic crisis and Japan. The Developing Economies 36 (3):332-351. doi:10.1111/j.1746-1049.1998.tb00222.x 